\title{
Adaptations of Three Cash Crops to Climate Change
}

\author{
Eming Sudiana*, Edy Yani, Lucky Prayoga, Darsono Darsono, \\ Edy Riwidiharso, Slamet Santoso
}

Faculty of Biology, Universitas Jenderal Soedirman, Indonesia

*Email: jungki_sudiana@yahoo.co.id

Submitted: 19 February 2020. Revised: 7 April 2020. Accepted: 4 July 2020

\begin{abstract}
Climate change is likely to lead to adaptations among important crop species. Elevational gradients can be used to illustrate the effects of climate change on crop adaptation patterns. The research aimed to determine adaptation patterns in crop species across an elevational (and therefore temperature and humidity) gradient. A factorial design was applied with two factors within a simple Randomized Complete Block Design, wherein the primary factor was elevation $(10-1,000 \mathrm{~m})$. Three crop species (long bean, common bean, and winged bean) were used as test species. Growth rate and flower number were used as adaptation parameters. The results indicated that these three cash crop species showed different adaptation patterns. Common bean showed the greatest vegetative growth at approximately $600 \mathrm{~m}$ in elevation, long bean at $400 \mathrm{~m}$ in elevation, and winged bean at $10 \mathrm{~m}$ in elevation. The results of this study indicate that the three tested agricultural crops have different adaptation patterns, and these results was the first finding to be published in Indonesia. For agriculture practices, it can be recommended that planting of these cash crops be adapted to the elevation of the planting area.
\end{abstract}

Key words: Adaptation Patterns; Cash Crops; Climate Change; Elevation Gradient; Growth Rate

How to Cite: Sudiana, E., Yani, E., Prayoga, L., Darsono, D., Riwidiharso, E., \& Santoso, S. (2020). Adaptations of Three Cash Crops to Climate Change. Biosaintifika: Journal of Biology \& Biology Education, 12 (2), 247-253

DOI: http://dx.doi.org/10.15294/biosaintifika.v12i2.23489

\section{INTRODUCTION}

Temperature is a primary regulatory factor for plant development. Climate change has caused not only an increase in temperature but also an increase in the probability of extreme temperature events, which can have major impacts on plant productivity (Hatfield \& Prueger, 2015). Of all the abiotic factors affecting morphological adaptation patterns in plants, temperature is the most dominant (Suzuki et al., 2014). Therefore, increases in temperature will be likely to result in a series of morphological, physiological, biochemical, and molecular alterations among plant species, and these changes will probably relate to negative effects on growth, productivity, and yield (Bita \& Gerats, 2013). The projected global daily temperature increase of $3^{\circ} \mathrm{C}$ (IPCC 2013) is expected to affect the growth rate, leaf number, and phenology of plants (Ray et al., 2019).

Morphological and physiological adaptations among plants exist to maintain the sustainability of a given species (Vadez, et al., 2010; Parmesan \& Hanley, 2015), and these adaptations can be used to assess species responses to climate change, particularly for crops (Johansson et al., 2015). Agricultural species show differential patterns in morphological adaptations and physiological dependencies in response to temperature increases caused by the climate change (Johansson et al., 2013, Sita et al., 2017; Adie et al., 2019). Understanding the impact of global climate change on crops is complicated, because required time spans to observe changes in temperate. However, King et al. (2013) suggested that an elevation gradient was a suitable tool to assess climate change responses, given that this gradient is associated with a decrease in temperature and, therefore, plant performance (Korner, 2011). Research that has used an elevation gradient as a surrogate for climate change, while controlling for other environmental factors, has successful represented climate change impacts on organisms and ecosystems (Wolkovich et al., 2012; Widhiono et al., 2017). Based on these findings, elevation gradients have been utilized in research on the effects of global climate change on crops (King et al., 2013).

It is suspected that crop species occurring in the tropics have adaptations that will improve their ability to survive the climate change (Luo, 2011). These adaptations include flowering mechanisms and phenology, which are reflected in changes in flower size, flowering time, and daily blooming time (King et al., 2013). Ray et al. (2019) suggested that crop species throughout the world have probably adapted their growth and flowering in response to climate change. Additionally, Raza et al. (2019) stated that morphological and physiological adaptations in flowering plants have already been observed due to increases in air temperature, including changes in growth rate, leaf number, and flower number. Temperature increase affects plants by introducing stress to physiological systems such as photosynthesis, respiration, nitrogen fixation, reproduction, and oxidative metabolism 
(Bucher, et al., 2017). It is therefore likely that climate change will relate to crop damage, including fertilization failures (Hatfield \& Prueger, 2015). The changes in flowering time in various sub-tropical regions and temperature stress had the most comprehensive and far-reaching effects on crops, leading to a severe reduction in yield potential (Bita \& Gerats, 2013). The most typical adaptation pattern to climate change observed in agricultural species is an earlier flowering period (Bucher, et al., 2017). Earlier flowering periods have also been observed in wild plant species (Johansson et al., 2013). Menzel et al. (2006) reported that nearly $78 \%$ of crops in 21 European countries have exhibited an earlier flowering time ( 2.5 days) over the past ten years. However, crop adaptations in response to climate change have never been assessed in Indonesia. Therefore, we investigated climate-related adaptations in crops across an elevation gradient. The aims of the research were to know the adaptations pattern of cash crops to climate change. The results of the study are expected to contribute to farming patterns for farmers and supporting adaptation programm for agriculture.

\section{METHODS}

This study was conducted at six locations situated at different elevations: Jambusari Village, Jeruklegi District, Cilacap Regency (7 41 '06 32", 109 01' 12 24", $50 \mathrm{~m}$ in elevation (meters above sea level); Gunung Tugel, South Purwokerto Subdistrict $\left(7^{\circ} 28\right.$ '03 92", 109 14' 06 35", $200 \mathrm{~m}$ in elevation); Sikapat Village, Sumbang Sub-district, Banyumas $\left(7^{\circ} 20\right.$ '00 43", 109 16' 29 49", $407 \mathrm{~m}$ in elevation.), Melung Village, Kedungbanteng District, Banyumas $\left(7^{\circ} 09\right.$ '46 38", 109 09' 06 66", $640 \mathrm{~m}$ in elevation), and Sangkanayu and Serang Villages, Karangreja District, Pubalingga (7 14 '48 41", 109 17' 28 91", 800 and $1,114 \mathrm{~m}$ in elevation, respectively). We used three crop species in this experiment; long bean (Vigna sinensis), winged bean (Psophocarpus tetragonolobus), and common bean (Phaseolus vulgaris),

A two-factor factorial design was utilized within a basic Randomized Complete Block Design (RCBD). The main factor was elevation (six locations), and the supporting factors were the three crop species. All three bean species were planted at the same time in April, 2019 (i.e., during the rainy season), using typical cultivation methods used by farmers when pesticides are not applied. Two hundred ninety individual plants of each species were planted at each of the six study locations.

Plant growth (stem height) and maturity (flower number) were observed every month for three months after planting. The experiment was done during the dry season planting period. Additional measured environmental variables included ambient air temperature, humidity, and light intensity.

We used an Analysis of Variance (ANOVA) to test for differences in crop growth (stem height) and maturity (flower number) at various elevations. Multivariate analyses were completed by assessing correlations of environmental factors (i.e., light intensity, humidity, and ambient air temperature) with stem height and flower number. Analyses were completed using SPSS Version 20.0.

\section{RESULTS AND DISCUSSION}

\section{Environmental condition}

The results of measurements of environmental conditions carried out during the study showed that the daily air temperature and light intensity and in the morning, afternoon and evening decreases in line with the increase in elevation. While air humidity increases with increasing altitude. The results of measurement of environmental conditions are presented in Table 1.

\section{Impact of elevation on plant growth}

Overall, the three bean species showed different growth patterns across the six study locations (Table 1, Figure 1), which indicated that the plant growth adaptations were species-dependent. This may be related to different optimum temperatures for each species.

In common bean, the maximum growth and growth rate at 7 and 35 days after planting (dap) were both significantly different $\left(\mathrm{F}_{5.23} . \mathrm{p}<0.001\right)$ across the study locations. The maximum stem height was $89.01 \pm 2.36 \mathrm{~cm}$ and was observed at $1,000 \mathrm{~m}$. In long beans, maximum plant height, maximum growth, and plant growth rate were significantly different $\left(\mathrm{F}_{5.26}, \mathrm{p}\right.$ $<0.001$ ) across study locations. The maximum stem height was $43.7 \pm 5.53 \mathrm{~cm}$ and was observed at $400 \mathrm{~m}$ in elevation. The maximum stem height observed in winged bean was found at $10 \mathrm{~m}$ in elevation $(102.02$ $\pm 16.86 \mathrm{~cm}$ ), which was significantly different relative to the other five study locations $\left(\mathrm{F}_{5.25} \mathrm{p}<0.001\right)$. The differentcies is likely due to naturally occurring plant species favoring a habitat with a certain temperature, (Kusumiyati et al., 2015). Bean plants originating from Europe tend to be more suitable in the highlands, while winged bean plants which are tropical plants are more suitable for high temperatures (Handayani et al., 2015). Wulandari et al. (2017) found that winged bean plant growth rates are influenced by local environmental factors, especially the daily air temperature at an altitude of $300 \mathrm{~m}$ above sea level. 
Table 1. Environmental condition of six different elevations during sampling periods (means \pm stdev)

Time Elevation (m asl) Temperature $\left({ }^{\circ} \mathrm{C}\right)$ Light intensity (lux) Humidity (\%)

\begin{tabular}{lllll}
\hline & 10 & $23.78 \pm 0.67$ & $3860.33 \pm 180.58$ & $63.67 \pm 1.80$ \\
& 200 & $20.89 \pm 1.27$ & $3500.22 \pm 440.55$ & $70.78 \pm 1.48$ \\
6:00 - 9:00 am & 400 & $19.33 \pm 0.71$ & $2140.11 \pm 314.72$ & $74.00 \pm 1.41$ \\
& 600 & $18.44 \pm 0.53$ & $1680.44 \pm 387.19$ & $76.89 \pm 1.36$ \\
& 800 & $17.44 \pm 0.53$ & $1359.89 \pm 169.34$ & $84.00 \pm 2.83$ \\
& 1000 & $16.44 \pm 0.73$ & $1119.89 \pm 95.61$ & $96.00 \pm 1.12$ \\
& 10 & $33.56 \pm 1.13$ & $13600.00 \pm 1502.25$ & $58.00 \pm 1.12$ \\
& 200 & $31.67 \pm 1.00$ & $12100.00 \pm 1017.08$ & $67.89 \pm 2.42$ \\
$10: 00$ am - 01:00 pm & 400 & $28.56 \pm 1.01$ & $10320.00 \pm 422.29$ & $70.22 \pm 1.56$ \\
& 600 & $27.89 \pm 1.05$ & $9100.33 \pm 2534.36$ & $74.00 \pm 2.55$ \\
& 800 & $26.33 \pm 1.12$ & $8599.67 \pm 974.50$ & $80.00 \pm 2.12$ \\
& 1000 & $16.44 \pm 0.73$ & $8159.89 \pm 818.59$ & $90.00 \pm 3.32$ \\
& 10 & $29.22 \pm 1.64$ & $7540.11 \pm 1080.46$ & $60.00 \pm 2.69$ \\
& 200 & $28.33 \pm 1.58$ & $6779.89 \pm 1220.21$ & $70.00 \pm 2.29$ \\
& 400 & $26.44 \pm 1.24$ & $5100.44 \pm 518.95$ & $71.78 \pm 2.86$ \\
$02: 00-05: 00 \mathrm{pm}$ & 600 & $24.33 \pm 1.58$ & $3047.78 \pm 658.86$ & $78.00 \pm 1.58$ \\
& 800 & $23.33 \pm 1.41$ & $2839.89 \pm 359.50$ & $82.00 \pm 2.35$ \\
& 1000 & $20.33 \pm 1.00$ & $2160.33 \pm 406.25$ & $93.00 \pm 3.00$ \\
\hline
\end{tabular}

Table 1. Stem heights at six locations observed at 7 and 35 days after planting (dap) (means \pm stdev)

\begin{tabular}{ccccccc}
\hline Elevation ( m asl) & \multicolumn{2}{c}{ Common bean (dap) } & \multicolumn{2}{c}{ long bean (dap) } & \multicolumn{2}{c}{ Wing bean (dap) } \\
\hline & 7 & 35 & 7 & 35 & 7 & 35 \\
\hline 10 & $2.26 \pm 0.90$ & $45.62 \pm 2.50$ & $2.52 \pm 0.44$ & $26.60 \pm 1.55$ & $2.38 \pm 0.79$ & $102.02 \pm 16.8$ \\
200 & $5.78 \pm 0.88$ & $62.76 \pm 4.03$ & $3.65 \pm 0.71$ & $22.56 \pm 5.44$ & $2.43 \pm 0.08$ & $99.97 \pm 14.81$ \\
400 & $7.03 \pm 1.40$ & $73.28 \pm 4.88$ & $3.04 \pm 1.39$ & $21.79 \pm 1.17$ & $2.19 \pm 0.40$ & $97.75 \pm 27.02$ \\
600 & $9.63 \pm 0.00$ & $82.25 \pm 0.00$ & $7.55 \pm 1.14$ & $43.78 \pm 5.55$ & $1.58 \pm 0.13$ & $71.45 \pm 8.78$ \\
800 & $12.22 \pm 0.74$ & $89.01 \pm 2.36$ & $0.00 \pm 0.00$ & $9.30 \pm 1.70$ & $0.00 \pm 0.00$ & $18.94 \pm 1.59$ \\
1000 & $8.20 \pm 0.47$ & $69.24 \pm 052$ & $0.00 \pm 0.00$ & $10.86 \pm 3.10$ & $0.00 \pm 0.00$ & $20.94 \pm 0.28$ \\
\hline
\end{tabular}

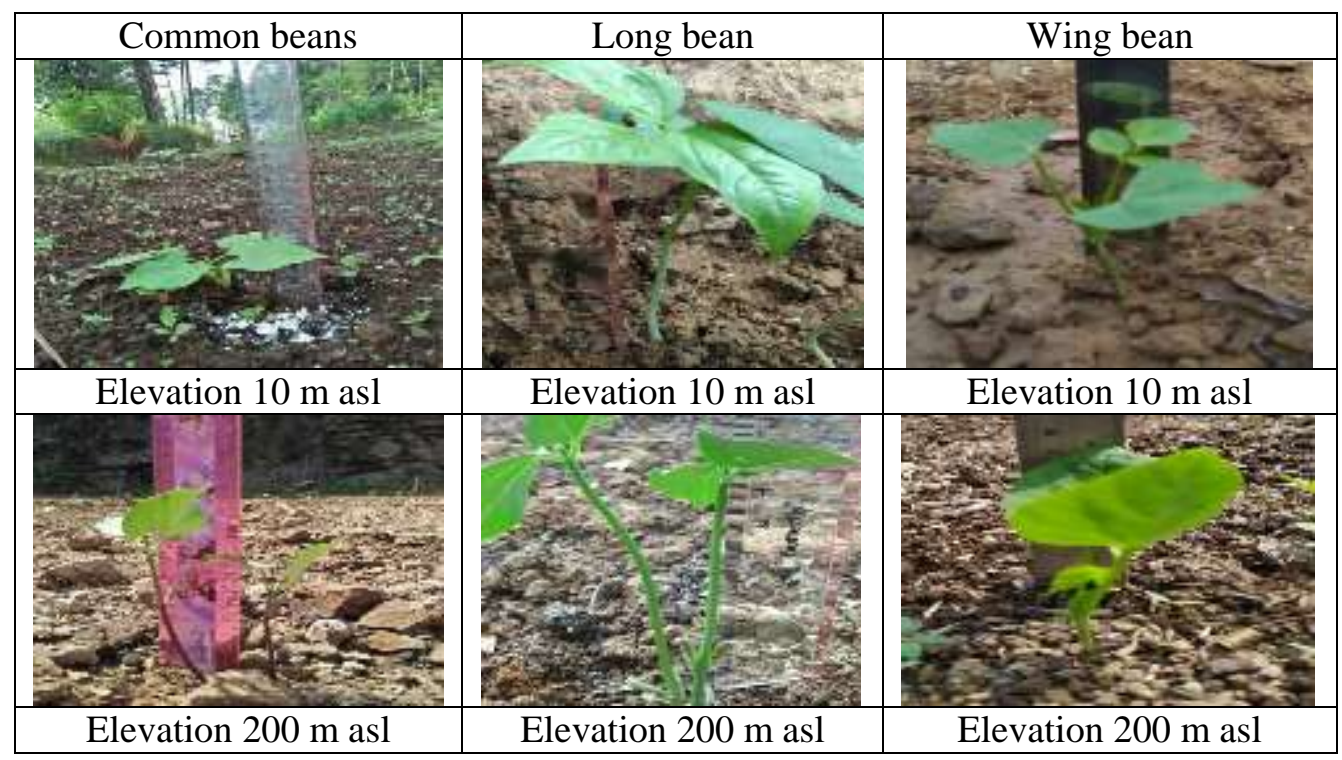




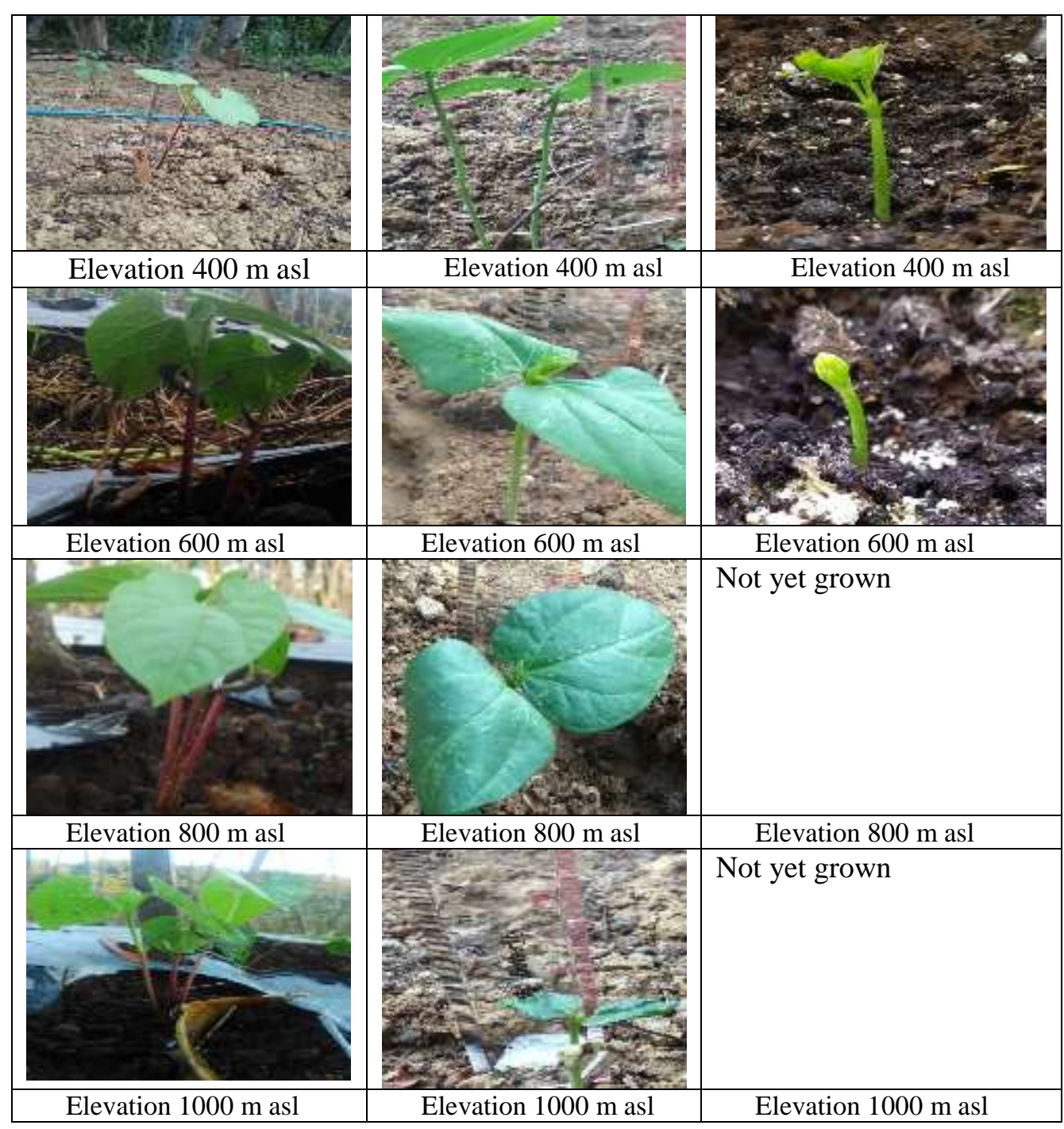

Figure 1. Plants growth after 7 days of planting at six different elevations

Elevation was the main factor affecting plant growth $\left(\mathrm{R}^{2}={ }_{0.91}\right.$, Fig. 2). Morphological adaptations to daily temperature stress differ among plant species (Bita \& Gerats, 2013). Decreases in temperature, especially average air temperature change, resulting from increases in elevation significantly affect plant growth and phenology, wherein an increase in the minimum air temperature may have the greatest im- pact. Minimum air temperatures are likely to increase under climate change (Hatfield \& Prueger, 2015). Although maximum temperature is affected by local conditions such as soil water content and evaporative heat loss (Crimmins, et.al., 2009), minimum air temperature is affected by mesoscale changes in atmospheric water vapor content. (Moore \& Lauenroth, 2017).
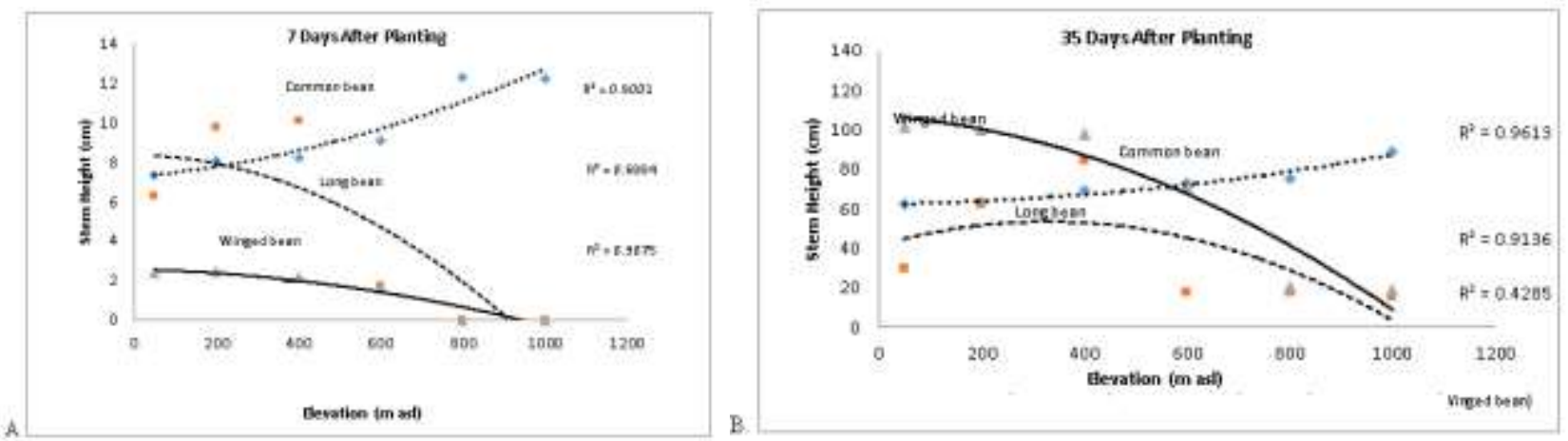

Figure 2. Correlations between elevation and the stem heights of three plants at 7 days after planting (A) and 35 days after planting (B) 
The observed differences in plant height and the rate of growth among species (Table 1), wherein long beans grew tallest at $800 \mathrm{~m}$ in elevation, common beans at $600 \mathrm{~m}$ in elevation, and winged beans at 10 $\mathrm{m}$ in elevation, indicated that these species differ in their daily temperature tolerances. Long bean reportedly grows best in temperatures of approximately $28^{\circ} \mathrm{C}$ (Tanzi et al, 2019). Extreme fluctuations in temperature would therefore cause reduced growth as a result of tradeoffs between respiration and evaporation (Hatfield \& Prueger 2015) Common bean is known to reach maximum growth at elevations of
$600 \mathrm{~m}$ with daily temperatures of approximately $30^{\circ} \mathrm{C}$. In contrast to these two species, winged bean appears to prefer areas with low soil moisture and high temperature (Tanzi et al., 2019); winged bean plants grow best at temperatures above $30^{\circ} \mathrm{C}$ (Chethan \& Chikkadevaiah, 2014).

\section{Impact of elevation on flower number}

Flower number, observed at the beginning and the end of the flowering period, varied significantly among species and across the six study locations $(\mathrm{F}$ 5,23. $\left.\mathrm{p}_{<0,01}\right)($ Table 2).

Table 2. Number of flowers of three cash crops species in different elevations at 28 and 49 day after planting

\begin{tabular}{ccccccc}
\hline Elevation (m asl) & common & bean (dap) & \multicolumn{2}{c}{ long bean (dap) } & \multicolumn{2}{c}{ Wing bean (dap) } \\
\hline & 28 & 49 & 28 & 49 & 28 & 49 \\
\hline 10 & $2.04 \pm 0.21$ & $25.04 \pm 1.60$ & $1.75 \pm 0.50$ & $1.69 \pm 0.24$ & $5.25 \pm 0.21$ & $7.83 \pm 2.03$ \\
200 & $2.15 \pm 0.14$ & $34.00 \pm 3.27$ & $0.46 \pm 0.42$ & $2.54 \pm 0.68$ & $6.25 \pm 1.34$ & $6.25 \pm 1.02$ \\
400 & $3.13 \pm 0.21$ & $35.75 \pm 9.84$ & $2.17 \pm 0.24$ & $1.46 \pm 0.25$ & $6.88 \pm 0.34$ & $7.54 \pm 1.08$ \\
600 & $2.71 \pm 0.37$ & $41.09 \pm 5.63$ & $0.72 \pm 0.47$ & $0.58 \pm 0.40$ & $2.21 \pm 0.48$ & $4.58 \pm 0.39$ \\
800 & $2.75 \pm 0.40$ & $41.84 \pm 5.95$ & $0.57 \pm 0.31$ & $0.58 \pm 0.40$ & $1.77 \pm 0.43$ & $3.98 \pm 0.65$ \\
1000 & $2.42 \pm 0.22$ & $38.20 \pm 5.99$ & $0.13 \pm 0.25$ & $0.21 \pm 0.16$ & $1.69 \pm 0.36$ & $2.75 \pm 0.44$ \\
\hline
\end{tabular}

The number of flowers borne on long bean plants at 49 dap decreased with an increase in elevation over $200 \mathrm{~m}$. A similar trend was observed in common bean over $800 \mathrm{~m}$. The greatest number of flowers borne on winged bean was found at $10 \mathrm{~m}$ in elevation (Table 2). These patterns are likely to be the result of temperature variation, wherein flowering time and the number of flowers borne by a plant tend to be influenced by maximum, rather than minimum, temperatures (Gray \& Brady, 2016) The results of correlation and regression analyses were; $\mathrm{R}^{2}=0.77$ for long beans at 49 dap, $R^{2}=0.64$, for common beans, and $R^{2}$ $=0.86$ for wing beans, respectively (Figure 3 ).

The difference are likely due to naturally occurring plant species favoring a habitat with a certain temperature. Handayani et al., (2015) found that total number of flower of wing bean, was affected by variety of the plant than environmental factors. Wulandari et al. (2017) found that total number of flower was influenced by local environmental factors, especially the daily air temperature at an altitude of $300 \mathrm{~m}$ above sea level.

Plant growth and reproduction are tightly regulated by seasonality for most species. Phenology, meaning the timing of flowering, is a seasonal event that is essential to successful reproduction. Although the initiation of flowering is typically mediated by changes in day length and, as such, is independent of temperature, the length of time required for flowers to develop to maturity is strongly temperature dependent, as are other growth processes (Tanzi et al., 2019). In both long bean and chickpea, daily temperature has a significant influence on both flowering time and the number of flowers produced by a plant. Both of these species initiate flowering when daily temperatures are approximately $35^{\circ} \mathrm{C}$ for six days, but they will fail to flower if daily temperatures exceed $34^{\circ} \mathrm{C}$ (Luo, 2011). In winged bean, the number of flowers produced is strongly influenced by both temperature and day length, wherein the species appears to prefer high temperature and long sunlight exposure (approximately 13 hours).

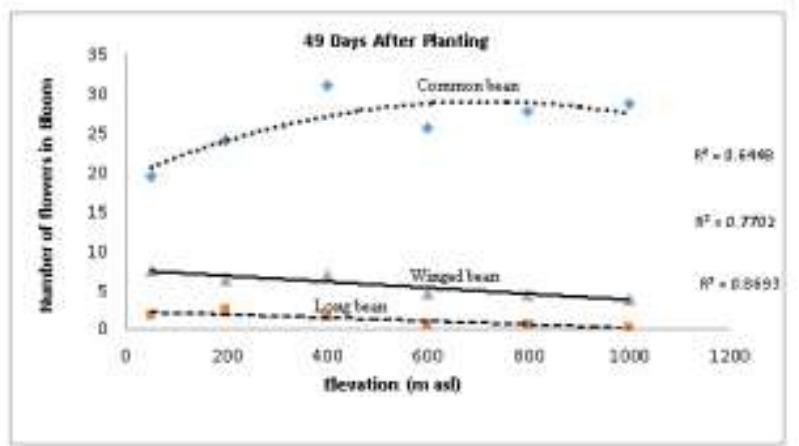

Figure 3. The number of flowers produced by three plant after 49 days at different elevations.

In our study, the observed differences in the number of flowers produced by a given bean species were the result of change in daily temperatures caused by differences in elevation at the study locations. The two species (long beans and wing bean) tended to produce fewer flowers along with an increase in elevation, which is a phenological adaptation to temperature decrease, while common bean tends to be more flowers in higher elevation. This finding may because the common bean is originally as a tropical facultative 
short-day legume that is now grown in tropical and temperate zones that temperature, solar radiation, and photoperiod play major roles in controlling common bean flowering time directly (Kakon et al., 2017), This pattern has also been observed in other plant species. In herbaceous plants, phenology is related to daily temperature, which further affects specific leaf area, nitrogen, phosphorus, and potassium concentrations in leaves, and water use efficiency (Bucher et al., 2017). In wild plants, lowland and high-elevation species have been shown to be associated with different optimum daily temperatures, and a pattern of separation between flowering time and the number of flowers produced has been observed (Hatfield \& Prueger, 2015). Aside from daily temperature, precipitation also affects flowering time and the number of flowers produced by a given plant (Siegmund et al., 2016), as do light intensity and day length (Rezazadeh et al., 2018).

The results of the study showed the patterns of adaptation of agricultural plants, especially in the growth rate and the number of flowers produced in the face of changes in daily air temperature which is described by changes in altitude. This result is the first discovery in Indonesia and is able to add new information for the development of agricultural cultivation, especially long bean, common bean and wing bean plants. So it can be recommended for farmers to cultivate these plants based on the elevation of the place.

\section{CONCLUSION}

Based on the results and discussion, it can be concluded that common bean showed the greatest vegetative growth at low temperatures (high elevation), and long bean at midle elevation and winged bean showed the greatest vegetative growth at high temperatures (low elevation). Therefore, we recommend cultivation of common bean in areas $>800 \mathrm{~m}$ in elevation, long bean at midle elevation $(600 \mathrm{~m})$ and cultivation of wing bean in areas $<400 \mathrm{~m}$ in elevation.

\section{ACKNOWLEDGEMENTS}

This research was supported Universitas Jenderal Soedirman in 2019 (Contract No:P/213/UN23/14/PN 12019) therefore, we thank the determinants of funding for this research Suwarto, Rifda Naufalin, and Imam Widhiono for permission to conduct this study

\section{REFERENCES}

Adie, M. M., Krisnawati, A., \& Hapsari, R. T. (2019). The Effect of Seed Position in Pod on The Seed Viability of Cowpea (Vigna unguiculata). Biosaintifika:
Journal of Biology \& Biology Education, 11(1), 6876.

Bita, C. A., \& Gerats, T. (2013). Plant tolerance to high temperature in a changing environment: scientific fundamentals and production of heat stress-tolerant crops. Frontiers in Plant Science. 4. 273

Bucher, S.F., König, P., Menzel, A., Migliavacca, M., Ewald, J., \& Römermann, C. (2017). Traits and climate are associated with first flowering day in herbaceous species along elevational gradients. Ecology and Evolution. 8: 1147-1158.

Cambridge University Press (2013). Climate Change 2013: Impacts, Adaptation and Vulnerability: Contribution of Working Group II to the Fourth Assessment Report of the Intergovernmental Panel on Climate Change. Cambridge University Press, Cambridge, U.K. and New York, NY.

Chethan, K. G. (2014). The effect of gamma rays on yield and yield attributes in Winged bean (Psophocarpus tetragonolobus (L) DC) Genotypes. BIOINFOLET-A Quarterly Journal of Life Sciences, 11(3b), 953-956.

Crimmins, T.A., Crimmins, M.A., \& Bertelsen, D., (2009). Flowering range changes across an elevation gradient in response to warming summer temperatures. Global Change Biology 15, 1141-1152,

Gray, S.B., \& Brady, S.M.. (2016). Plant developmental responses to climate change. Development Biology (419), 64-77

Handayani, T., Kusmana, Liferdi, \& Hidayat, I.M. (2015). Karakterisasi Morfologi dan Evaluasi Daya Hasil Sayuran Polong Kecipir (Psophocarpus tetragonolobus (L.) DC). J. Hort. 25(2), 126-132.

Hatfield, J.L., \& Prueger, J.H,. (2015) Temperature extremes: Effect on plant growth and development. Weather and Climate Extremes, 10. 4-10

Johansson, J., Bolmgren, K., \& Jonzen, N., (2013). Climate change and the optimal flowering time of annual plants in seasonal environments. Global Change Biology 19, 197-207.

Johansson, R., Luebehusen, E., Morris, B., Shannon, H., \& Meyer, S., (2015). Monitoring the impacts of weather and climate extremes on global agricultural production. Weather and Climate Extremes. 10, 6571

Kakon, S.S., Khan, M.S.A., Choudhury, J.A., Ali, M.Z., Aziz, M.A., 2017 Influence of sowing time based temperature on flowering and seed yield of French bean (Phaseolus vulgaris L.). AARC J. Agri., 15(1), 77-84

King, G.M., David C. Frank, D.C., Gugerli, F., \& Fonti, P., (2013) Tree growth response along an elevational gradient: climate or genetics? Oecologia 173, 15871600.

Ko"rner, C. (2011). The use of 'altitude' in ecological research. TRENDS in Ecology and Evolution. 22(11), 569-574.

Kusumiyati , W., Sutari , N., \& Raniska, (2015). Respons pertumbuhan, hasil, dan kualitas hasil buncis 
tegak terhadap pemberian berbagai dosis kompos dan interval panen pada Inceptisols Jatinangor. Jurnal Kultivasi 14(2), 1-8

Luo, Q. (2011). Temperature thresholds and crop production: a review. Climatic Change 109, 583-598.

Menzel, A., Sparks, T,H,. Estrella, N,. Koch, E,. Asaa, A,. Ahas, R,. Alm-Kulber, K,. Bissolli, P,. Braslavska,O,. Briede,A., Chemelewski, F.M., Crepinsek, Z., Curne, Y.,2006. European phenological response to climate change matches the warming pattern. Global Change Biology. 12(10), 1969-1976

Parmesan, C., \& Hanley, M.E., (2015), Plants and climate change: complexities and surprises. Annals of Botany 116, 849-864.

Ray, D.K., West, P.C., Clark, M., Gerber, J.S., Prishchepov, A.V., \& Chatterjee, S., (2019) Climate change has likely already affected global food production. PLoS ONE 14(5), e0217148.

Raza, A., Xu, J., Mehmood, S.S., Zou, X., Zhang, X., Lu, Y., 2019. Impact of Climate Change on Crops Adaptation and Strategies to Tackle Its Outcome: A Review. Plants. 8. 34

Rezazadeh, A. Harkess, R.L., and Telmadarrehei, T. (2019). The Effect of Light Intensity and Temperature on Flowering and Morphology of Potted Red Firespike. Horticulturae, 4, 36

Siegmund, J.F., Wiedermann, M., Donges, J.F., and Donne, R.V. (2016) Impact of temperature and precipitation extremes on the flowering dates of four German wildlife shrub species Biogeosciences, 13, 5541-5555.

Sita, K., Sehgal, A, Hanumantha, R.B., Nair, R.M., Vara Prasad, P.V., Kumar, S., Gaur, P.M, Farooq, M., Siddique, K.H.M., Varshney, R.K., \& Nayyar, H.,
(2017). Food Legumes and Rising Temperatures: Effects, Adaptive Functional Mechanisms Specific to Reproductive Growth Stage and Strategies to Improve Heat Tolerance. Front. Plant Sci. 8, 1658.

Suzuki, N., Mittler, R., Rivero, R.M., Shulaev, S.,\& Blumwald, E. (2014) Abiotic and biotic stress combinations. New Phytologist 203, 32-43

Tanzi, A.S., Eagleton, E.W., Ho, W.K., Wong, Q.N., \& Massawe, F,. (2019). Winged bean (Psophocarpus tetragonolobus (L.) DC.) for food and nutritional security: synthesis of past research and future direction. Planta, 1-21.

Vadez, V., Berger, J.D., Warkentin, T., Asseng, S., Pasala Ratnakumar, P., K. Poorna, K., Rao, C., Gaur, P.M., Munier-Jolain, N., Larmure, A., Voisin, A.S., Sharma, H.C., Pande, S., Sharma, M., Krishnamurthy, L., \& Zaman, M.A., (2010). Adaptation of grain legumes to climate change: a review. Agronomy for Sustainable Development, 32(1), 31-44.

Widhiono, I., Sudiana, E., \& Darsono, (2017). Diversity of Wild Bees along Elevational Gradient in an Agricultural Area in Central Java, Indonesia. Psyche, Article ID 2968414, 5 pages

Wolkovich, E., Cook, B.I., Allen, J.M., Crimmins, T.M., Betancourt, J.L., \& Cleland, E. E., (2012). Warming experiments underpredict plant phenological responses to climate change. Nature. 485(7399), 494497

Wulandari, P. I. A., Purnamaningsih, S. L., \& Kuswanto. (2017). Upaya Peningkatan Pembungaan dan Hasil Polong Pada Tiga Genotip Kecipir (Psopocarpus tetragonolobus). Jurnal Produksi Tanaman. 5(7), 1143-1152 